\title{
Achieving Sustainable Development Goals: Does Government Expenditure Framework Matter?
}

\author{
Emeka Osuji ${ }^{1}$ \\ ${ }^{*}$ Stanley Emife Nwani ${ }^{1}$

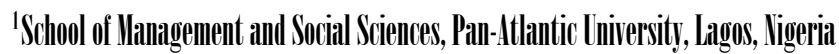

\begin{abstract}
The purpose of this study was to examine the effectiveness of government expenditure framework in tracking social, economic, and environmental sustainable development goals (SDGs) in Nigeria. Using quarterly data (Q1:2000-Q4:2018), the study applied vector autoregression, variance decomposition, and impulse response estimation techniques. The estimates indicated a long-run association between government expenditure and SDGs indicators, with mixed impacts. In the short-run, government expenditure reduced poverty, while in the long-run it amplified poverty; government expenditure hurt SDG of rapid economic growth in the long-run, but promoted SDG of quality education in both short-run and long-run, through improvement in school enrolment. Furthermore, government spending amplified healthrelated SDGs in the long-run. Finally, government spending was found to adversely affect environmental sustainability through rising $\mathrm{CO} 2$ emission. From the empirical evidence, the study concluded that the public sector lacks the capacity to attain SDGs from environmental, growth, and poverty alleviation perspectives. The study contradicted the institutional and Wagner's theories but validated Hardin's tragedy of the commons. It proposes an effective public/private partnership, to improve spending outcomes, as the inevitable strategic action, if the attainment of the SDGs is to become a reality in Nigeria.

Keywords: Government expenditure, economic sustainability, social sustainability, environmental sustainability, vector autoregression, variance decomposition
\end{abstract}

JEL: H5, II, P37

Sustainable development has continued to gain currency with concerted efforts towards making the world a better place for current and future generations. The most frantic universal attempt at building a sustainable world was at the global declaration of the Millennium Development Goals (MDGs) in 2000. The milestone achievements through the MDGs laid the foundation for the global declaration of 17 international goals and 169 worldwide targets to be achieved in 15 years starting from September 25, 2015, to 2030. The Sustainable Development Goals (SDGs) encapsulate inclusive growth, social development (health, education, gender equality) and environmental protection. The SDGs and their targets challenge nations to be strategic, ambitious and innovative by establishing transparent, efficient, and inclusive strategies to implement and realize this daunting global development agenda down to the regional level (Voluntary review on SDGs in Brazil, 2017). One of such strategies is the mobilization and sanctioning of financial resources (expenditure framework) through partnership betwe- 
en the government and the private sector (Alinska, Filipiak and Kosztowniak, 2018) in frontier economies that include Nigeria.

This study is primarily motivated by the peculiar structural characteristics of the Nigerian economy. The economy is monolithic and volatile (Central Bank of Nigeria, 2018). It is the world headquarters of poverty (The World Bank, 2019), where growth is sluggish at an average of 0.36 per cent from 20162018, mortality rates (human and industrial) are high, life expectancy is low at 54.5 years (the third lowest in the world), maternal death is high, illiteracy rate at over 38 percent depicts that over 70 million Nigerians are unable to read and write, coupled with over 10 million out-of-school children (Vangaurd, 2018) and environmental issues are pronounced. Also, the economy is ranked $141^{\text {st }}$ in the world (per capita income of $\$ 2,049$ in 2018) and truncated by poor business environment evident in infrastructure deficits, hostile tax policies, weak institutional framework, corruption, and policy inconsistency and insecurity (Evans and Kelikume, 2019). This depicts that social sustainability is far from reality. On environmental sustainability, waste generation has been on the rise, flooding incidence, excessive grazing, herders-farmers clashes, bush burning, gas flaring, and oil spills constitute threats to environmental limits in the country (Albert, Amaratunga and Haigh, 2018; Evans and Kelikume, 2019; Ndeh et al., 2017).

Although a plethora of literature exists on public spending and sustainable development goals (see Alinska et al., 2018; Hege and Brimont, 2018; Khaijamang et al., 2018; Martin and Walker, 2015; Seyedsayamdost, 2018; Schmidt-Traub and Shah, 2015), all of these studies do not relate effectively to Nigeria, thus, an empirical vacuum, a gap that this study attempted to close. Also, studies that examined government expenditure and sustainable development in Nigeria erroneously utilized real gross domestic product (RGDP) as a proxy variable for sustainable development (see Apata, 2017; Babatunde, 2018; Dibie, 2018; Ebong et al., 2016). RGDP does not adequately capture the social and environment dimension of development, its rather a mere measure of economic growth. These studies neglected the social and environmental dimensions to sustainable development, a misspecification gap in literature. This article addressed this gap by decomposing sustainable development into economic, social, and environmental dimensions. To adequately contribute to existing knowledge in theory and methodology, the study significantly extended the frontiers of the institutional, increasing state activities and tragedy of the common theories of sustainability models. The study is also significant methodologically by improving on existing estimation techniques adopted by previous studies (see Alinska et al., 2018; Apata, 2017; Babatunde, 2018; Dibie, 2018; Ebong et al., 2016) by applying a dynamic vector autoregression estimation technique, variance decomposition, and impulse response to estimate the relationship between government expenditure framework and social, economic, and environmental sustainability. The ultimate findings of the study practically enlightened 


\section{Osuji \& Nwani}

SDGs policy executors in Nigeria that government expenditure framework is only effective in attaining health and education related targets, but does not significantly amplify the actualization of zero poverty, rapid economic growth, and environmental related SDGs in the long-run.

Following the introductory section is literature review contained in part two and in section three, we presented the methodology of the study. Section four details the analysis of data, section five discusses the findings of the study, and section six concludes the study with policy implications.

\section{LITERATURE REVIEW}

\section{Theoretical Underpinnings}

This empirical study on sustainable development is triangulated by the institutional theory, the Wagner's law, and the tragedy of the commons theory by Gareth Hardin.

\section{-The Institutional Approach to Sustainable Development}

The pursuit of sustainable development and its associated targets require the creation of alliances through policy instruments and financing of the developmental processes. The alliances include synergy between the public and private sectors. This entails the integration of SDGs into the operations of firms. The attendant result of the synergy is the stimulation of sustainable development, which through regulations creates a favorable environment for the achievement of SDGs. Figure 1 shows the interaction amongst institutions, regulations, policy tools and instruments, and reflects that adequate and incorruptible financing promotes the attainment of SDGs. Alinska et al. (2018) developed the institutional theory. In their analysis, they stressed the roles of the public sector in SDGs attainment. Their theory is one of the undergirding theories for this study. The other theories are Wagner's increasing State activities theory and the Garret Hardin's theory of the tragedy of the commons.

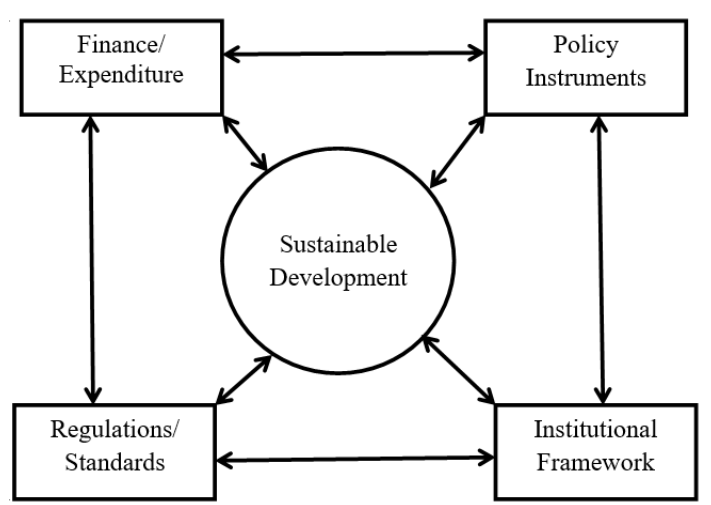

Source: Alinska, Filipiak and Kosztowniak (2018)

Figure 1. Institutional Approach to Sustainable Development 


\section{-Wagner's Theory of Public Expenditure}

Wagner $(1883 ; 1893)$ in his seminar work observed the existence of a positive co-movement between the size of public expenditure and economic development. This was first observed in the German economy, and later, the analyses expanded to other economies. Wagner's theory of increasing state activities could be examined from different perspectives. For instance, state activities could be in terms of total government expenditure, the proportion of total government expenditure in gross domestic product (GDP) and the growth rate of the public sector to the entire economy.

According to Wagner's theory, increasing state activities is attributable to three factors. One: as the fundamental roles of the government increases, government expenditure tends to rise. The fundamental functions of the state include administration, defense, infrastructure, and maintenance of laws and order. Two: rising social complexities (pollution, crime) and other vices due to industrial and urban development. For the society curb these misnomers, state controls through government policy direction and intervention in health, education, and sanitation (merit goods) spending to improve the social welfare of the citizenry accounts for rising government expenditure. This category of state expenditure is what Lybeck (1988) referred to restructuring society expenditure. Three: the income elasticity of demand for the public good is elastic. That is, as the economy grows, per capita income rises, and the demand for merit goods increases. Therefore, the government spends more on the provision of pubic or merit goods and services. The provision of these goods promotes equity in the distribution of state resources and curbing natural monopolies.

The validity of Wagner's theory continued to surface in empirical and descriptive analyses (see Afonso and Alves, 2017; Afzal and Abbas, 2010; Gould, 1983; Hook, 1962; Keho, 2016; Mann, 1980; Neck and Schneider, 1988; Yousefi and Abizadeh, 1992) affirm support for Wagner's law based on the analysis of cross-section, time series, and panel data for various countries and regions. Other studies that confirmed the validity of Wagner's law include (Chletsos and Kollias, 1997; Funashima, 2017; Halicioglu, 2003; Henrekson, 1993; Kalam and Aziz, 2009; Magazzino, Giolli and Mele, 2015; Mohammadi, Cak and Cak, 2008).

\section{-The Theory of the Tragedy of the Commons}

The theory of the Tragedy of the Commons is an economic cum environmental theory that explains how the exploitation of natural resources beyond the environmental limits could lead to common tragedy for all. The theory proposed by Lloyd (1833) and popularized by Hardin (1968). In their theory, the term "the commons" refers to freely opened to exploit natural resources for public consumption. For instance, oil, wildlife, aquatic lives, pasture land, the oceans, the atmosphere, lumber, amongst others. Therefore, the theory posits that the overexploitation of the shared resources without regula- 


\section{Osuji \& Nwani}

tions or privatization would lead to a negative impact on society in the long-run. This implies a threat to lives under the waters, wildlife and other valuable resources that future generations have right to enjoy. The excessive utilization of these resources eventually results in environmental damage, which does not promote environmental sustainability. Hardin suggested that to promote sustainability in the utilization of these resources; state regulatory policy is germane. This could be in the form of total restriction, selective harvesting, imposing of fines, taxation or outright sale of the common property to the private sector are some of the solutions to the problem of the tragedy of the common. An awareness campaign is another crucial factor. To this end, the implementation of these solutions requires a financial commitment from the government through its fiscal framework. This theory further triangulates the study from the dimension of the impact of government expenditure on environmental sustainability encompasses in SDGs 13 and 14 proxied by $\mathrm{CO}_{2}$ emission per capita.

\section{Empirical Review}

In development literature, the concept of sustainable development geometrically gained currency with its alternative usage as inclusive growth and pro-poor growth. In 1972, the first debates about the relationship between the environment and development took place in Stockholm. In 1987, the report on our collective future (popularly known as the Bruntland Report) presented the maiden edition of sustainable development. Thus, "sustainable development connotes the development that satisfies the needs of the present generation by not compromising future generations' right to meet their own needs". Sustainable development goals are global targets and indicators aimed at promoting transgenerational equity, its lofty objectives have attracted the attention of empirical studies (Allen, Metternicht and Wiedmann, 2018; Golding et al., 2017; Hogan et al., 2018; Kumar, Kumar and Vivekadhish, 2016) with varying findings.

Hogan et al. (2017) examined the SDG target 3.8 - the achievement of universal health coverage, quality service coverage and financial protection using 16 tracer indicators for 183 countries. They computed the SDG index using geometric means. The result revealed that health service coverage index improved life expectancy by an average of 21 years.

Alinska et al. (2018) investigated the vitality of the public sector in sustainable Development in Poland between 1995 and 2015 using the classical linear regression model and the dynamic vector error correction models. They found that GDP growth in Poland is driven by the final consumption expenditure of households, total general government expenditure, and total general government revenue. Yet, variance decomposition result confirms a low share of total government expenditure in explaining changes in GDP. However, social spending and fixed investment expenditures actively propelled growth. 
Other studies have been partial in their analysis by focusing on either of the dimensions of sustainable development while ignoring mostly the social and environmental dimensions. In this regard, the work of Odhiambo (2018) on the dynamics of public expenditure concentrated on the economic perspective of sustainable development while neglecting the social and environmental angles. His study employed the error-correction based autoregressive distributed lag bounds testing approach and multivariate Granger-causality models. The study reported a unidirectional Grangercausality from government expenditure to economic growth for the Kenyan economy in both short-run and long-run. In an earlier study by the same author (Odhiambo, 2018) for the South African economy, the study documented a bi-directional causality between government expenditure and economic growth in the short-run, while in the long-run, a unidirectional relationship existed that ran from economic growth to government expenditure. Also, government expenditure does not only affect growth directly but does that through human development (Ebong et al., 2016) and environmental sustainability. Thus, their work left out the all-important social and environmental dimensions.

In a disaggregated analysis of the impact of government expenditure on economic growth in Nigeria, Ebong et al. (2016) analyzed a multiple regression model using the cointegration and error correction techniques to ascertain the sectors that amplify growth between 1970 and 2012. The study reports the absence of any significant effect of government capital expenditure on economic growth. However, the social dimensions were found to propel economic growth significantly, that is, government expenditure on education and health drove economic growth in both short-run and longrun in Nigeria. As the search for a comprehensive study on the three dimensions of sustainable development continued, Nwani et al. (2018) investigated the role of public health expenditure, economic growth, and environmental pollution on health outcomes between 1981 and 2017. Their study employed the modern ARDL bounds test to establish the possibility of a long-run co-movement amongst the variables. The results show that public health expenditure and environmental pollution bore significant impacts on the social sector through health outcomes. Although the former positively influence the social sector, the latter hurts the social sector in both short-run and long-run.

Besides, the theoretical and empirical reviews, it is crystal clear that sustainability studies conducted in Nigeria differ in findings and perspectives, and most studies ignored the social and environmental dimensions to sustainability. To fill these gaps in the literature, this study incorporated the social and environmental tracer indicators to complement the economic indicators to extend the institutional, increasing state activities, and environmental theory of the tragedy of the commons. Against the theoretical and empirical backdrops, we propose the following hypotheses:

$\mathrm{H}_{01}$ : Government expenditure propels the attainment of poverty eradication sustainable 


\section{Osuji \& Nwani}

development goal (SDG).

$\mathrm{H}_{02}$ : Government expenditure hurts rapid economic growth sustainable development goal $(\mathrm{SDG})$.

$\mathrm{H}_{03}$ : Government expenditure does not enhance the actualization of quality education sustainable development goal (SDG).

$\mathrm{H}_{04}$ : Government expenditure does not promote health related sustainable development goal $(\mathrm{SDG})$.

$\mathrm{H}_{05}$ : Through government expenditure, sustainable development goal (SDG) of environmental protection is achievable.

\section{METHODOLOGY}

\section{Sample and Procedure}

The data employed for analyses in this study emerged from two secondary sources: The World Development Indicator and Central Bank of Nigeria's Statistical Bulletin between Q1:2000 and Q4:2018. The data series on total government expenditure (GEXP), government revenue (GRVE), debt (DEBT), agricultural output (AGRI), and industrial output (INDO) were collected from the CBN Statistical Bulletin, while poverty index (POVTY), primary school enrolment rate (PSER), carbon-dioxide emission $\left(\mathrm{CO}_{2}\right)$, life expectancy (LEXP), and GDP growth rate (YG) were sourced from the World Development Indicators published by The World Bank in 2018. Nigeria was selected for this study because of the high incidences of poverty, sluggish growth, falling quality of education, poor health outcomes, and environmental issues despite the huge financial commitment to sustainable development agenda directly under the presidency.

\section{Model}

The institutional theory, Wager's theory, and Hardin's theory provide the hypothesis that linked government spending to economic, social, and environmental sustainability. This study employs the vector autoregression (VAR) approach to analyze how effective government expenditure is in attaining SDGs. The choice of this method and the model specification of our study was abstracted from the earlier work of Alinska et al. (2018) that investigated the roles of the public sector in the attainment of SDGs for Poland. However, we departed from their study by extending the modelling of SDGs to two other areas previously neglected by the same study, namely, social and environmental sustainability, thus, precluding the econometric problem of omitted variable bias (Gujarati, 2003). 
The general VAR model expressed as follows:

$$
\begin{aligned}
& y_{1 t}=\Phi_{1}+\Phi_{11} y_{1 t-1}+\Phi_{12} y_{2 t-1}+\Omega_{11} y_{1 t-2}+\Omega_{12} y_{2 t-2}+\epsilon_{1 t} \\
& y_{2 t}=\Omega_{1}+\Phi_{21} y_{1 t-1}+\Phi_{22} y_{2 t-1}+\Omega_{21} y_{1 t-2}+\Omega_{12} y_{2 t-2}+\epsilon_{2 t}
\end{aligned}
$$

The compact form of the above VAR equations is expressed in the equation below:

$$
y_{t}=\Omega+\Phi_{1} y_{t-1}+\Phi_{2} y_{t-2}+\mu_{t}
$$

where:

\section{$\Omega$ depicts an $n \times 1$ Column vector}

$\phi_{\text {'s }}$ are the $\mathrm{n} \times \mathrm{n}$ square metrics

$\mu_{t}$ is an $\mathrm{n} \times 1$ column vector of serially uncorrelated vector of innovations variable which is independently, identically and normally distributed with zero mean and constant variance $\left\{\mu_{t} \sim i i d n\left(0, \sigma^{2}\right)\right\}$.

If $y_{t}$ is a column vector ( $\left.n \times 1\right)$ matrix which encompasses all the logged variables in the model, the VAR model establishes a link between the current $\mathrm{y}_{\mathrm{t}}$, its lags $\left(\mathrm{y}_{\mathrm{t}-\mathrm{i}}\right)$ and the white noise variable $\left(\mu_{t}\right)$.

Furthermore, the Granger causality test is employed to estimate equations 4 to 11 in an attempt to determine causal linkages between government expenditure and the three dimensions of sustainable development captured in five econometric models.

$$
\begin{aligned}
& \text { POVTY }_{t}=\Omega_{0}+\sum_{t-1}^{n} \Omega_{1} \ln \text { GEXP }_{t-1}+\sum_{t-1}^{n} \Omega_{2} \ln \text { GRVE }_{t-1} \sum_{t-1}^{n} \Omega_{3} \operatorname{lnDEBT_{t-1}}+\sum_{t-1}^{n} \Omega_{4} \ln A G R I_{t-1} \\
& +\sum_{t-1}^{n} \Omega_{5} Y G_{t-1}+\mu_{t} \\
& \ln \text { GEXP }_{t}=\Omega_{0}+\sum_{t-1}^{n} \Omega_{1} \text { POVTY }_{t-1}+\sum_{t-1}^{n} \Omega_{2} \ln \text { GRVE }_{t-1} \sum_{t-1}^{n} \Omega_{3} \operatorname{lnDEBT_{t-1}}+\sum_{t-1}^{n} \Omega_{4} \ln A G R I_{t-1} \\
& +\sum_{t-1}^{n} \Omega_{5} Y G_{t-1}+\mu_{t} \\
& Y G_{t}=\Omega_{0}+\sum_{t-1}^{n} \Omega_{1} \operatorname{lnGEXP}_{t-1}+\sum_{t-1}^{n} \Omega_{2} \operatorname{lnGRVE}_{t-1} \sum_{t-1}^{n} \Omega_{3} \operatorname{lnDEBT}_{t-1}+\sum_{t-1}^{n} \Omega_{4} \text { PSER }_{t-1} \\
& +\sum_{t-1}^{n} \Omega_{5} \operatorname{CO}_{t-1}+\mu_{t} \\
& \ln G E X P_{t}=\Omega_{0}+\sum_{t-1}^{n} \Omega_{1} Y G_{t-1}+\sum_{t-1}^{n} \Omega_{2} \ln G R V E_{t-1} \sum_{t-1}^{n} \Omega_{3} \ln D E B T_{t-1}+\sum_{t-1}^{n} \Omega_{4} P S E R_{t-1} \\
& +\sum_{t-1}^{n} \Omega_{5} \operatorname{CO}_{t-1}+\mu_{t}
\end{aligned}
$$




$$
\begin{aligned}
& \text { PSER }_{t}=\Omega_{0}+\sum_{t-1}^{n} \Omega_{1} \ln \text { EEXP }_{t-1}+\sum_{t-1}^{n} \Omega_{2} \ln G R V E_{t-1} \sum_{t-1}^{n} \Omega_{3} \ln D E B T_{t-1}+\sum_{t-1}^{n} \Omega_{4} L E X P_{t-1} \\
& +\sum_{t-1}^{n} \Omega_{5} Y G_{t-1}+\mu_{t} \\
& \ln \text { GEXP }_{t}=\Omega_{0}+\sum_{t-1}^{n} \Omega_{1} \text { PSER }_{t-1}+\sum_{t-1}^{n} \Omega_{2} \ln \text { GRVE }_{t-1} \sum_{t-1}^{n} \Omega_{3} \operatorname{lnDEBT_{t-1}}+\sum_{t-1}^{n} \Omega_{4} L E X P_{t-1} \\
& +\sum_{t-1}^{n} \Omega_{5} Y G_{t-1}+\mu_{t} \\
& L E X P_{t}=\Omega_{0}+\sum_{t-1}^{n} \Omega_{1} \operatorname{lnGEXP_{t-1}}+\sum_{t-1}^{n} \Omega_{2} \ln G R V E_{t-1} \sum_{t-1}^{n} \Omega_{3} \ln D E B T_{t-1}+\sum_{t-1}^{n} \Omega_{4} C O 2_{t-1} \\
& +\sum_{t-1}^{n} \Omega_{5} \ln I N D O_{t-1}+\mu_{t} \\
& \ln G E X P_{t}=\Omega_{0}+\sum_{t-1}^{n} \Omega_{1} L E X P_{t-1}+\sum_{t-1}^{n} \Omega_{2} \ln G R V E_{t-1} \sum_{t-1}^{n} \Omega_{3} \ln D E B T_{t-1}+\sum_{t-1}^{n} \Omega_{4} C O 2_{t-1} \\
& +\sum_{t-1}^{n} \Omega_{5} I N D O_{t-1}+\mu_{t} \\
& \mathrm{CO}_{t}=\Omega_{0}+\sum_{t-1}^{n} \Omega_{1} \ln \text { GEXP }_{t-1}+\sum_{t-1}^{n} \Omega_{2} \ln G R V E_{t-1} \sum_{t-1}^{n} \Omega_{3} \ln A G R I_{t-1}+\sum_{t-1}^{n} \Omega_{4} I N D O_{t-1} \\
& +\sum_{t-1}^{n} \Omega_{5} Y G_{t-1}+\mu_{t} \\
& \ln \operatorname{GEXP}_{t}=\Omega_{0}+\sum_{t-1}^{n} \Omega_{1} \operatorname{CO}_{t-1}+\sum_{t-1}^{n} \Omega_{2} \ln \operatorname{GRVE}_{t-1} \sum_{t-1}^{n} \Omega_{3} \ln A G R I_{t-1}+\sum_{t-1}^{n} \Omega_{4} I N D O_{t-1} \\
& +\sum_{t-1}^{n} \Omega_{5} Y G_{t-1}+\mu_{t}
\end{aligned}
$$

From equations 4 through 13, the following statements of hypotheses are constructed:

$$
\begin{aligned}
& \mathrm{H}_{0}=\sum_{t-1}^{n} \Omega_{i}=0, \text { and } \sum_{t-1}^{n} \Phi_{i}=0 \\
& \mathrm{H}_{1}=\sum_{t-1}^{n} \Omega_{i} \neq 0, \text { and } \sum_{t-1}^{n} \Phi_{i} \neq 0
\end{aligned}
$$

From equations 4 to 13 , if the estimates $\Omega_{2}$ and $\Phi_{2}$ are statistically significant, a bi-directional causation will exist. But if $\Omega_{2}$ is statistically significant and $\Phi_{2}$ is insignificant, it implies a unidirectional causality from the explained to the explanatory variable. However, should $\Phi_{2}$ is statistically significant, 
and $\Omega_{2}$ is otherwise, the unidirectional causality flows from the exogenous variable to the endogenous variable.

\section{RESULTS}

\section{Summary Statistics}

The summary statistics presented in Table 1 (see Appendix-I) indicate the basic measures of central tendency and variation in the variables. The standard deviation of the variables shows that the environmental factor is the most stable variable ( $\mathrm{s} . \mathrm{d}=0.096)$ while total public debt is the most unstable with a standard deviation of 5142.063. Surprisingly, all the independent variables are more stable than all the dependent variables in various models. The skewness of the variables lies between -0.0067 and 1.3269, while GRVE, INDO, POVTY, PSER, YG and AGRI have long tail to the left, GEXP, LEXP, DEBT and $\mathrm{CO}_{2}$ have long tail to the right. The result of the kurtosis implies that PSER, YG and DEBT are peaked, all other variables are flat. To further explore the nature of the data series to be employed for the empirical analysis, their stationarity property is examined using Lenin, Lin and Chu group unit root test and other stationarity tests for each of the models in their either log-log form or partial-log form.

\section{Unit Root Result}

To determine the stationarity property of the variables in the five models, a group unit root test was conducted. Proposed Lenin, Lin and Chu. The test assumes common unit root process. The common unit root result indicates that the variables in all the models are respectively stationary at first difference. Also, the results from other techniques for stationarity test i.e., Im, Pesara and Shin, ADF, and the PP group tests that assume individual unit root process validates the findings of Levin, Lin and Chu test that reports that all the variables in the models are stationary in their first difference (see Tables 2, 3, 4, 5 \& 6-Appendix-II,III,IV,V,VI).

\section{Cointegration Results}

The test for the existence of long-run co-movement between the selected SDGs and their explanatory variables was examined using the Unrestricted Rank Trace Test. The result for each of the model is presented in Tables 7-11 (see Appendix-VII, VIII, IX,X,XI). The results imply the presence of long-run association between the selected SDGs and government expenditure including other control variables in the model. The long-run co-movement amongst these variables indicate that the vector error correction model is appropriate for the estimation of the parameters of the models.

\section{DISCUSSION}




\section{Osuji \& Nwani}

In this section, the study succinctly discussed the results of the vector error correction model (VECM) estimation and related estimations and the proposed hypotheses were tested.

\section{Hypothesis One: Impact of government expenditure on poverty}

$\mathrm{H}_{01}$ : Government expenditure propels the attainment of poverty eradication sustainable development goal (SDG).

Short-Run VECM Estimate

$$
\begin{aligned}
& \text { POVTY }=0.18+0.61 D(P O V T Y)_{-1}+0.01 D(P O V T Y)_{-2}-2.93 D(\text { LNGEXP })_{-1}+ \\
& 0.02 D(L N E X P)_{-2}-1.50 D(L N G R V E)_{-1}+0.51 D(L N G R V E)_{-2}-0.12 D(L N D E B T)_{-1}+ \\
& 1.07 D(L N D E B T)_{-2}-1.97 D(L N A G R I)_{-1}-0.07 D(L N A G R I)_{-2}-0.11 D(Y G)_{-1}+ \\
& 0.05 D(Y G)_{-2}-0.41 E C M_{-1}
\end{aligned}
$$

\section{Long-Run VECM Estimate}

$$
\begin{aligned}
& \text { POVTY }=-136.52+9.97(\text { LNGEXP })_{t}-18.19(\text { LNGRVE })_{t}-0.35(L N D E B T)_{t}+ \\
& 14.13(\text { LNAGRI })_{t}+3.44(Y G)_{t}
\end{aligned}
$$

The short-run of VECM model reveals that government expenditure in the previous period bears a negative impact on the poverty index, while the two-period lag of government expenditure bears a positive impact on poverty incidence in Nigeria. This result implies that government expenditure in Nigeria does not stably influence poverty. Thus, within the first period, usually one year, government expenditure leads to a reduction in poverty incidence. However, in the second period (year), government expenditure instead fuels poverty incidence. The justification for this result is that government expenditure in Nigeria is dominated by recurrent expenditure, which is majorly a stop-gap measure for poverty alleviation.

However, in the long-run, government expenditure in Nigeria instead promotes and intensifies poverty than alleviate it. Thus, as government expenditure rises, poverty incidence increased by close to 10 percent. Though this appears impossible, however, the high rate of unproductive expenditure, coupled with corruption, economic and social instability, justify this finding. Also, successive governments have spent more on security, social transfer, salaries, compensations, debt servicing, and electioneering at the expense of agriculture, ICT, industrialization, energy, health, education, and other social overhead. 
From the result of the impulse response test, evidence abounds that innovations in government expenditure bear positive impact on poverty except during the second lag period. The variance decomposition result indicates that the economic growth rate and public debt account for 17.39 and 14.38 percent of the variations in poverty within ten years. Unexpectedly, government expenditure only contributes a minuscule of 0.88 percent to changes in poverty level within ten years.

Therefore, within the context of this analysis, we accept the null hypothesis that government expenditure bears a positive impact on the poverty rate in Nigeria. This implies that government expenditure does not possess the capacity to achieve poverty eradication in Nigeria. Instead, because the public sector is corrupt, rising government expenditure intensifies poverty menace in Nigeria. The mechanism is such that rising government expenditure emerges from rising tax rate and public borrowing, leading to lower disposable income and crowding out effect on private sector investment capacity. Thus, consumption reduces, and industry shrinks, unemployment heightens, and poverty rises.

The reliability of the estimated parameters is tested using the Lagrange multiplier (LM) test and the inverse roots of autoregressive (AR) characteristic polynomial. The Rao $f$-statistic value of 0.451 with a $p$-value of 0.9972 and the linear rational expectation (LRE) test value of 16.90 with a $p$-value of 0.9972 implies the acceptance of the null hypothesis which stipulates the absence of serial correlation in the model. Further, the inverse root outcome reveals that all the point falls within the unit circle; this indicates that the VECM parameter estimates are reliable, stable, and robust for policy formulation.

Hypothesis Two: Impact of government expenditure on economic growth

$\mathrm{H}_{02}$ : Government expenditure hurts rapid economic growth sustainable development goal (SDG)

Short-Run VECM Estimate

$Y G=-0.15+0.43 D(Y G)_{-1}+0.10 D(Y G)_{-2}-1.35 D(L N G E X P)_{-1}+4.90 D(L N E X P)_{-2}+$ $0.30 D(L N G R V E)_{-1}-0.69 D(L N G R V E)_{-2}+0.44 D(L N D E B T)_{-1}-0.79 D(L N D E B T)_{-2}+$ $0.02 D(P S E R)_{-1}-0.07 D(P S E R)_{-2}+1.23 D(C 02)_{-1}-7.40 D(C 02)_{-2}-0.20 E C M_{-1}$

\section{Long-Run VECM Estimate}

$Y G=94.90-15.94(L N G E X P)_{t}+6.94(L N G R V E)_{t}+2.90(L N D E B T)_{t}+0.04(P S E R)_{t}-$ $102.48(\mathrm{CO} 2)_{t}$ 


\section{Osuji \& Nwani}

In the short-run, empirical evidence reveals that government expenditure does not propel economic growth within the immediate past period. However, after two periods, government expenditure seems to impact positively on economic growth. Further, the study examined the long-run cointegration effect of government expenditure on economic growth. The long-run VECM equation affirmed that government expenditure hurts economic growth rate in Nigeria. The simple implication of this finding alludes to the earlier empirical evidence that indicates the inability of government expenditure to curb poverty. To ascertain the reliability of our findings, the LM test and the inverse root AR test show that the model is free from serial correlation, and the results are stable and reliable. Thus, we affirm the position of the null hypothesis that government expenditure is not productive enough to drive the Nigerian economic growth in line with sustainable development goals target.

\section{Hypothesis Three: Impact of government expenditure on education proxied by school enrolment rate}

$\mathrm{H}_{03:}$ Government expenditure does not enhance the actualization of quality education sustainable development goal (SDG).

\section{Short-Run VECM Estimate}

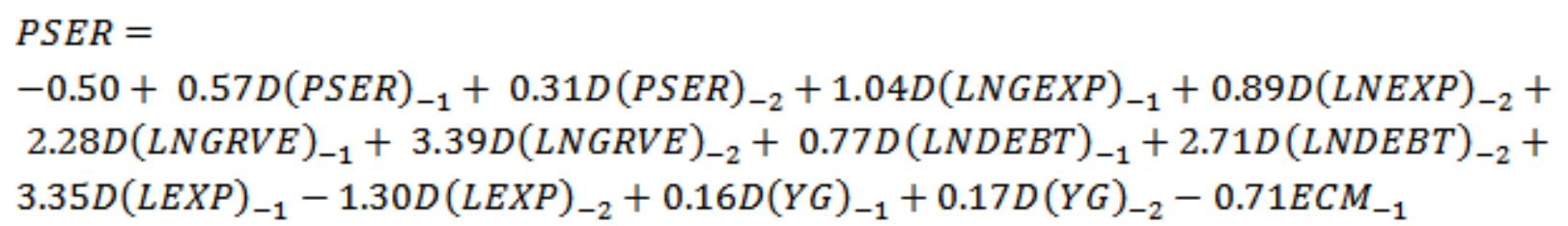

Long-Run VECM Estimate

$P S E R=222.04+92.15(L N G E X P)_{t}-23.07(L N G R V E)_{t}+23.72(L N D E B T)_{t}-$ $21.55(L E X P)_{t}-1.54(Y G)_{t}$

The sustainable development goal 4 is about quality education. Obtaining quality and sound education within the suitable age bracket is the foundation upon which improvement in human lives and sustainable development rest. In our empirical estimate, we quantified education using the primary school enrolment rate (PSER). The VECM result reveals that in both short-run and long-run, government expenditure has a positive impact on the quality of education in Nigeria. This finding is justified by the fact that public expenditure on education leads to the construction of more schools and training of more teachers, which further leads to increment in school enrolment rate. Thus, the higher the rate of enrolment, the better education indices, it increases awareness and innovations, leading to 
sustainable development. The post estimation analyses reveal that innovations in government expenditure framework positively influence the quality of education from the third through to the tenth year. The variance decomposition result indicates that economic growth rate accounts for 17.39 percent of the variations in quality education while government expenditure accounts for only 0.13 percent.

Also, the LM test for the presence of autocorrelation shows that the LRE test has a value of 9.04 and Rao $f$-stat is 0.24 with a corresponding $p$-value of 1.0000 . The test result implies the absence of serial correlation in the model, and as such, the parameter estimates are unbiased. The stability and reliability test results affirm this position conducted using the inverse AR root characteristic polynomial approach, as all the point falls within the unit circle.

Hypothesis Four: Impact of government expenditure on health-related SDG of life expectancy $\mathrm{H}_{04}$ : Government expenditure does not promote health related sustainable development goal (SDG).

\section{Short-Run VECM Estimate}

$$
\begin{aligned}
& L E X P=-0.012+0.94 D(L E X P)_{-1}+0.19 D(L E X P)_{-2}-0.05 D(\text { LNGEXP })_{-1}+ \\
& 0.18 D(L N E X P)_{-2}+0.0002 D(L N G R V E)_{-1}-0.02 D(L N G R V E)_{-2}- \\
& 0.0009 D(L N D E B T)_{-1}+0.02 D(L N D E B T)_{-2}+0.73 D(C O 2)_{-1}+0.05 D(C 02)_{-2}- \\
& 0.01 D(L N I N D O)_{-1}-0.02 D(L N I N D O)_{-2}-0.70 E C M_{-1}
\end{aligned}
$$

\section{Long-Run VECM Estimate}

\section{$L E X P=$}

$-43.38+1.09(L N G E X P)_{t}-0.57(L N G R V E)_{t}-1.09(L N D E B T)_{t}+27.05(L E X P)_{t}-$ $1.91(L N I N D O)_{t}$

Despite the growing attention of the government on health and wellness, the impact of government expenditure on health has continued to produce inconsistent impacts. In this study, our empirical result in the short-run shows mixed findings for the influence of government expenditure on health rated SDG of life expectancy at birth. Government expenditure lagged by one period hurts health and wellness, while the lag of government expenditure by two periods promotes health and wellness of Nigerians. However, from the long-run co-integrating equation, government expenditure positively affects the SDG of good health in the country. Thus, we fail to accept the null hypothesis and fail to reject the alternative hypothesis that government expenditure has a positive impact on health SGDs in Nigeria. 


\section{Osuji \& Nwani}

The impulse response test validates our rejection of the null hypothesis, as innovations in government expenditure framework bear a positive impact on health indicators in all the periods. Also, the variance decomposition result indicates that changes in government expenditure accounts for about 9 percent variations in health rated indices.

To further ascertain the reliability and stability of this model, the LM test and inverse root AR test were applied. The LM test with LRE stat of 10.169 and $p$-value of 1.0000 , and the Rao $f$-test of 0.267 with same probability value as the LRE stat implies the absence of autocorrelation in the model. All points fell within the unit root circle, implying that the estimated parameters are stable and reliable for policy formulation and forecasting.

Hypothesis Five: Impact of government expenditure framework on environmental sustainability (proxied by $\mathrm{CO}_{2}$ emission per capita)

$\mathrm{H}_{05}$ : Through government expenditure, sustainable development goal (SDG) of environmental protection is achievable.

\section{Short-Run VECM Estimate}

$\mathrm{CO} 2=$

$-0.02+0.21 D(C 02)_{-1}-0.07 D(C O 2)_{-2}+0.09 D(L N G E X P)_{-1}+0.11 D(L N E X P)_{-2}+$

$0.03 D(L N G R V E)_{-1}-0.0009 D(L N G R V E)_{-2}+0.17 D(L N A G R I)_{-1}+0.03 D(L N A G R I)_{-2}+$

$0.18 D(L N I N D O)_{-1}+0.21 D(L N I N D O)_{-2}+0.02 D(Y G)_{-1}+0.001 D(Y G)_{-2}-0.31 E C M_{-1}$

\section{Long-Run VECM Estimate}

$$
\begin{aligned}
& C O 2=7.22+0.14(L N G E X P)_{t}-0.05(L N G R V E)_{t}+0.30(L N A G R I)_{t}+1.21(L N I N D O)_{t}+ \\
& 0.006(Y G)_{t}
\end{aligned}
$$

Environmental sustainability encompasses SDGs 13, 14, and 15. The use of $\mathrm{CO}_{2}$ emission per capita as a proxy variable for environmental sustainability abounds in literature. However, this study related it to government expenditure framework. The relationship or nexus between $\mathrm{CO}_{2}$ and environmental sustainability is such that, when $\mathrm{CO}_{2}$ emission rises, environmental sustainability worsens. The VECM result reveals that government expenditure framework incontrovertibly has a positive impact on $\mathrm{CO}_{2}$ emission in the long-run and short-run. Because $\mathrm{CO}_{2}$ emission is inversely related to environmental sustainability, therefore, government expenditure bears a negative impact on environmental sustainability. 
The test of hypothesis result confirms the acceptance of the null hypothesis that states that government expenditure bears a negative impact on environmental sustainability via a positive impact on $\mathrm{CO}_{2}$ emission per capita.

The post estimation tests indicate the absence of serial correlation in the model as affirmed by the Rao $f$-stat and the LRE result. The impulse response test reveals that innovations in government expenditure framework bear a negative impact on environmental sustainability between the third and tenth periods. The variance decomposition result shows that industrialization variable accounts for over 15 percent of the variations in $\mathrm{CO}_{2}$ emission in Nigeria. The inverse root AR characteristic polynomial test indicates that all the points fell within the unit root circle, and as such, implies that the VECM estimates are stable and reliable.

\section{CONCLUSION}

This study has examined the efficacy of government expenditure framework in achieving social, economic and environmental SDGs tracers' indicators in Nigeria using VAR, variance decomposition, impulse response, and Granger causality tests by using quarterly data from Q1:2000 to Q4:2018. The results of the estimations have indicated that health and education related SDGs are significantly response to government expenditure framework, while poverty, rapid growth and environmental SDGs are significantly inhibited by government spending. In line with the institutional theory, the study found that the public sector does not have the capacity to solely propel the SDGs agenda in Nigeria. In corroboration with Wagner's law and Hardin tragedy of the common theory, the study also found that rising government expenditure does not address environmental and growth challenges in the country.

\section{IMPLICATIONS}

The outcomes of this study show that public spending does not matter as such in driving the sustainability processes in Nigeria. Although it does for social SDGs which are health and education related, it does not for economic and environmental SDGs indices. This is the reason the nation is bedeviled by a plethora of economic and environmental scourges like inequality, poverty, corruption, unemployment and macroeconomic shocks, oil spills, air pollution, gas flaring, carbon dioxide emission among others. The multiplicity of these challenges has significantly neutralized the potency of public spending on socio-economic and environmental sustainability drive.

The findings of this study lend credence to the theoretical positions of the institutional and Wagner's theories that government expenditure addresses social development and sustainability. This is possible through health and education variables as established in the outcomes of our estimations. In addition, 


\section{Osuji \& Nwani}

slow economic growth and weak environmental protection remained significant problems that cause welfare losses to Nigerians. The inability of government expenditure to combat environmental challenges drives its theoretical strength from the Hardin's theory of the tragedy of the common. The overall theoretical implications of this study for Nigeria are consistent with existing empirical outcomes (Alinska et al., 2018; Ebong et al., 2016) that reported a low share of total government expenditure in explaining changes in GDP for Poland and the absence of any significant effect of government capital expenditure on economic growth for Nigeria. Also, while most of the existing studies employed the cointegration test, our study utilized the VECM methodology which considers the time variance and dynamics in sustainability.

The ultimate findings of the study practically enlightened SDGs policy executors in Nigeria that government expenditure framework is only effective in attaining health and education related targets, but does not significantly amplify the actualization of zero poverty, rapid economic growth, and environmental related SDGs in the long-run.

The government of Nigeria at all levels needs to resuscitate and accelerate agricultural development in order to actualize the SDGs goal of poverty eradication at due date. Also, to attain SDG of rapid economic growth in the long-run, the government should contract higher but sustainable level of debt, improve her revenue base and encourage school enrolment rate. On environmental protection, there is urgent need for awareness creation on the hazards of unhealthy environmental practices like gas flaring, oil spills, carbon emission, bush burning, and indiscriminate waste disposal. In concord with the institutional approach to sustainability, there is need for the government to enter into partnership agreement with the private sector. The sustainability agenda should be incorporated into the operations of all firms. Programs such as green health and green education, green production and operations should be built into the operational capacity of private sector across industries.

\section{LIMITATIONS AND FUTURE DIRECTIONS}

Finally, while this study made a bold attempt at establishing the impact of public expenditure on the three dimensions of sustainability, its limitations should, however, be noted. A country specific study of this nature lacks the ability to effectively and suitably produce findings that are generalizable due to varying structural, social, economic, political, and environmental conditions across borders. Future studies should examine whether government expenditure framework does matter for a panel of countries from Sub-Saharan Africa, Asia, Eastern Europe, and Southern America where the quest for sustainability is paramount. The Pedroni Panel cointegration analysis and dynamic least squares should be utilized to determine the fixed and random effects of government expenditure on the dimen- 
International Journal of Management, Economics and Social Sciences

sions of sustainable development goals. To distinguish between the appropriateness of both effects, the Hausman's test is strongly recommended. The use of robust and sophisticated estimation techniques could provide more insight for policy implications.

\section{REFERENCES}

Afonso, A. \& Alves, J. (2017). Reconsidering Wagner's law: Evidence from the functions of the government. Applied Economics Letters, 24(5): 346-350. https://doi.org/10.1080/13504851.2016.1192267

Afzal, M. \& Abbas, Q. (2010). Wagner's law in Pakistan: Another look. Journal of Economics and International Finance, 2(1): 12-19. https://doi.org/10.5897/JEIF.9000123

Albert, O. N., Amaratunga, D. \& Haigh, R. P. (2018). Evaluation of the impacts of oil spill disaster on communities and its influence on restiveness in Niger Delta region in Nigeria. Procedia Engineering, 212, 1054-1061. https://doi.org/10.1016/j.proeng.2018.01.136

Alinska, A., Filipiak, B. \& Kosztowniak, A. (2018). The importance of the public sector in sustainable development in Poland. Sustainability, 10(9): 32-78. https://doi.org/10.3390/su10093278

Allen, C., Metternicht, G. \& Wiedmann, T. (2018). Initial progress in implementing the sustainable development goals: A review of evidence from countries. Sustainability Science, 13(5): 1453-1467. https://doi.org/10.1007/s11625-018-0572-3

Apata, T. G. (2017). Exploration of public spending and gross domestic product's growth in agricultural sector: Comparative analysis of Nigerian and Malaysian agricultural sector. African Journal of Economic and Sustainable Development, 6(3): 119-137. https://doi.org/10.1504/AJESD.2017.089943

Babatunde, S. A. (2018). Government spending on infrastructure and economic growth in Nigeria. Economic ResearchEkonomskaistraž ivanja, 31(1): 997-1014. https://doi.org/10.1080/1331677X.2018.1436453

Central Bank of Nigeria (2018). Annual statistical bulletin. Retrieved December 15, 2019, from http://www.cenbank.gov.ng

Chletsos, M., \& Kollias, C. (1997). Testing Wagner's law using disaggregated public expenditure data in the case of Greece. Applied Economics, 29(3): 371-377. https://doi.org/10.1080/000368497327155

Dibie, R. (2018). Public management and sustainable development in Nigeria: Military- bureaucracy relationship. London: Routledge. https://doi.org/10.4324/9781315194219

Ebong, F., Ogwumike, F. Udongwo, U. \& Ayodele, O. (2016). Impact of government expenditure on economic growth in Nigeria: A disaggregated analysis. Asian Journal of Economics and Empirical Research, 3(1): 113-121. https://doi.org/10.20448/journal.501/2016.3.1/501.1.113.121

Evans, O. \& Kelikume, I. (2019). The impact of poverty, unemployment, inequality, corruption and poor governance on Niger Delta militancy, boko haram terrorism and Fulani herdsmen attacks in Nigeria. International Journal of Management, Economics and Social Sciences, 8(2): 58-80. https://doi.org/10.32327/IJMESS/8.2.2019.5.

Funashima, Y. (2017). Wagner's law versus displacement effect. Applied Economics, 49(7): 619-634. https://doi.org/10.1080/00036846.2016.1203063

Golding, N., Burstein, R. Longbottom, J. Browne, A. J. Fullman, N. Osgood-Zimmerman, A. \& Dwyer-Lindgren, L. (2017). Mapping under -5 and neonatal mortality in Africa, 2000-15: A baseline analysis for the sustainable development goals. The Lancet, 390(10108): 2171-2182. https://doi.org/10.1016/S0140-6736(17)31758-0

Gould, F. (1983). The growth of public expenditures: Theory and evidence from six advanced democracies. In C.E. Taylor (Ed.), Why governments grow: Measuring public sector size, 217-239. Beverly Hills, London, New Delhi: Sage Publications.

Gujarati, D. N. (2003). Basic Econometrics (4 ${ }^{\text {th }}$ Ed). Singapura: McGraw-Hill.

Halicioĝ lu, F. (2003). Testing Wagner's law for Turkey, 1960-2000. Review of Middle East Economics and Finance, 1(2): 129140. https://doi.org/10.1080/1475368032000139279

Hardin, G. (1968). The tragedy of the commons. Science, 162(3859): 1243-1248. https://doi.org/10.1080/19390450903037302

Hege, E. \& Brimont, L. (2018). Integrating SDGs into national budgetary processes. Studies, (05/18). IDDRI, Paris, France.

Henrekson, M. (1993). Wagner's law-a spurious relationship? Public Finance, 46(3): 406-415.

Hogan, D. R., Stevens, G. A. Hosseinpoor, A. R. \& Boerma, T. (2018). Monitoring universal health coverage within the sustainable development goals: Development and baseline data for an index of essential health services. The Lancet Global Health, 6(2): e152-e168. https://doi.org/10.1016/S2214-109X(17)30472-2

Hook, E. (1962). The expansion of the public sector-study of the development of public civilian expenditures in Sweden during the years 1913-58. Public Finance, 17, 289- 312.

Kalam, M. A. \& Aziz, N. (2009). Growth of government expenditure in Bangladesh: An empirical enquiry into the validity of Wagner's law. Global Economy Journal, 9(2): 185-162. https://doi.org/10.2202/1524-5861.1451

Keho, Y. (2016). Testing Wagner's law in the presence of structural changes: New evidence from six African countries (19602013). International Journal of Economics and Financial Issues, 6(1): 1-6.

Khaijamang, M, Kaushiki, S. Bichitrananda, S. Indrani, M. Neeraj, K. Prayag, S.R. \& Sangita, M. (2018) On states' social sector spending and sustainable development goals. Reserve Bank of India Occasional Papers, 39, 1-2.

Kumar, S., Kumar, N. \& Vivekadhish, S. (2016). Millennium development goals (MDGS) to sustainable development goals 


\section{Osuji \& Nwani}

(SDGS): Addressing unfinished agenda and strengthening sustainable development and partnership. Indian Journal of Community Medicine, 41(1): 1-4. https://doi.org/10.4103/0970-0218.170955

Lloyd, W. F. (1833). Two lectures on the checks to population: Delivered before the University of Oxford, in Michaelmas Term 1832. JH Parker.

Lybeck, J. A. (1988). Comparing government growth rates: The non-institutional vs. the institutional approach. In Contributions to Economic Analysis, 171, 29-47. Elsevier.

Magazzino, C., Giolli, L. \& Mele, M. (2015). Wagner's Law and Peacock and Wiseman's displacement effect in European Union countries: A panel data study. International Journal of Economics and Financial Issues, 5(3): 812-819.

Mann, A. J. (1980). Wagner's law: An econometric test for Mexico, 1925-1976. National Tax Journal, 33(2): 189-201.

Martin, M. \& Walker, J. (2015). Financing the sustainable development goals: Lessons from government spending on the MDGs, 1-68. http://hdl.handle.net/10546/556597

Mohammadi, H., Cak, M. \& Cak, D. (2008). Wagner's hypothesis: New evidence from Turkey using the bounds testing approach. Journal of Economic Studies, 35(1): 94-106. https://doi.org/10.1108/01443580810844442

Ndeh, E. S., Okafor, J. O. Akpan, G. U. \& Olutoye, M. A. (2017). Environmental impacts of crude oil spillages on water in Ibeno local government area of Akwa Ibom state, Nigeria. Bayero Journal of Pure and Applied Sciences, 10(1): 315-319. http://dx.doi.org/10.4314/bajopas.v10i1.49

Neck, R. \& Schneider, F. (1988). The growth of the public sector in Austria: An exploratory analysis. In Contributions to Economic Analysis, 171, 231-263. Elsevier. https://doi.org/10.1016/B978-0-444-70426-9.50015-9

Nwani, S. E., Kelani, F. A. Ozegbe, A. E. \& Babatunde, O. H. (2018). Public health expenditures, environmental pollution and health outcomes: Evidence from Nigeria. South Asian Journal of Social Studies and Economics, 2(2): 1-15. https://doi.org/10.9734/sajsse/2018/v2i225846

Odhiambo, N. M. (2018). Public expenditure and economic growth in Kenya: A multivariate dynamic causal linkage. Working Paper 24/2018, 1-20.

Schmidt-Traub, G. \& Shah, A. (2015). Investment needs to achieve the sustainable development goals. Paris and New York: Sustainable Development Solutions Network. Retrieved December 16, 2019, from https://www.jstor.org/stable/pdf/resrep15864.pdf?acceptTC=true\&coverpage=false\&addFooter=false

Seyedsayamdost, E. (2018). Millennium development goals: Impact on national strategies and spending. Development Policy Review, 36(S1): 059-88. https://doi.org/10.1111/dpr.12314

The World Bank (2019). Poverty and Equity Data. Retrieved December 17, 2019, from http://povertydata.worldbank.org/poverty/country/NGA

Vangaurd (2018). Thirty Eight percent of Nigerians are illiterates. Retrieved December 18, 2019, from https://www.vanguardngr.com/2018/12/38-of-nigerians-are-illiterates/

Voluntary Review (2017). Sustainable Development Goals, Brazil. Retrieved December 17, 2019, from https://sustainabledevelopment.un.org/content/documents/15806Brazil_English.pdf

Wagner, A. (1883). Finanzwissenschaft. 4(1). CF Winter.

Wagner, A. (1892). Grundlegung der politischen Ökonomie 1, CF Winter'sche verlagshandlung.

Yousefi, M. \& Abizadeh, S. (1992). Wagner's law: New evidence. Atlantic Economic Journal, 20(2). Retrieved December 19, 2019, from https://www.questia.com/library/journal/1G1-12827721/wagner-s-law-new-evidence 
Appendix-I

\begin{tabular}{|c|c|c|c|c|c|c|c|c|c|c|}
\hline & $\overline{\text { GEXP }}$ & $\overline{\text { GRVE }}$ & INDO & $\overline{\text { LEXP }}$ & $\overline{\text { POVTY }}$ & $\overline{\text { PSER }}$ & $\overline{Y G}$ & $\overline{\text { DEBT }}$ & $\overline{\mathrm{CO}_{2}}$ & $\overline{\text { AGRI }}$ \\
\hline Maximum & 7885.590 & 11611.57 & 13849.32 & 55.86250 & 74.78333 & 103.3000 & 15.18406 & 20974.11 & 0.776250 & 17635.49 \\
\hline Std. Dev. & 1821.290 & 2982.037 & 1382.319 & 2.652729 & 6.911478 & 10.55062 & 3.649772 & 5142.063 & 0.096270 & 3821.951 \\
\hline Skewness & 0.409613 & 0.006777 & -0.643725 & 0.085913 & -0.051635 & -1.319357 & -0.011362 & 1.326932 & 0.117660 & -0.322387 \\
\hline Kurtosis & 2.494055 & 1.899720 & 2.741992 & 1.907285 & 1.606463 & 4.193487 & 3.331393 & 3.769704 & 2.091898 & 2.106201 \\
\hline Sum & 246876.4 & 482984.5 & 885621.8 & 3819.600 & 4862.267 & 6870.267 & 472.2000 & 571266.0 & 46.88000 & 911326.8 \\
\hline Sum Sq. Dev. & $2.49 \mathrm{E}+08$ & $6.67 \mathrm{E}+08$ & $1.43 \mathrm{E}+08$ & 527.7729 & 3582.639 & 8348.667 & 999.0626 & $1.98 \mathrm{E}+09$ & 0.695096 & $1.10 \mathrm{E}+09$ \\
\hline Observations & 76 & 76 & 76 & 76 & 76 & 76 & 76 & 76 & 76 & 76 \\
\hline
\end{tabular}

Table 1. Summary Statistics 
Series: POVTY, LNGEXP, LNGRVE, LNDEBT, LNAGRI, YG

\section{Cross-}

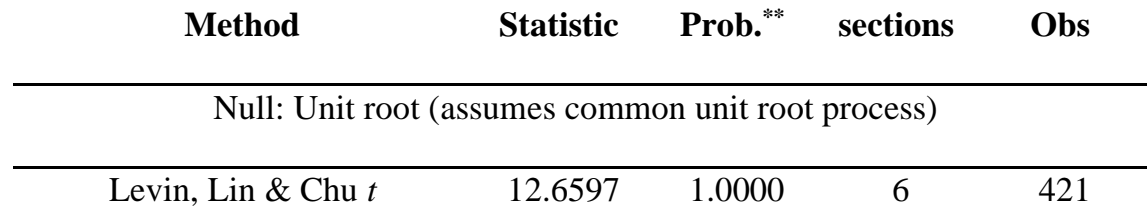

Null: Unit root (assumes individual unit root process)

\begin{tabular}{ccccc}
\hline Im, Pesaran and Shin W-stat & -6.87395 & 0.0000 & 6 & 421 \\
ADF - Fisher Chi-square & 72.9300 & 0.0000 & 6 & 421 \\
PP - Fisher Chi-square & 100.654 & 0.0000 & 6 & 444 \\
& & & & \\
\hline $\begin{array}{l}\text { Source: Authors' Computation using EViews 10 } \\
\text { ** Probabilities for Fisher tests are computed using an asymptotic Chi-square distribution. } \\
\text { All other tests assume asymptotic normality. }\end{array}$
\end{tabular}

Table 2. Group Unit Root Test: Summary (Model 1) 
Series: YG, LNGEXP, LNGRVE, LNDEBT, PSER, $\mathrm{CO}_{2}$

Cross-

\begin{tabular}{ccccc} 
Method & Statistic & Prob. $^{* *}$ & sections & Obs \\
\hline Null: Unit root (assumes common unit root process) & \\
\hline \multicolumn{2}{l}{} \\
\hline Levin, Lin \& Chu $t$ & 2.91761 & 0.9982 & 6 & 424
\end{tabular}

Null: Unit root (assumes individual unit root process)

\begin{tabular}{lllll}
\hline Im, Pesaran and Shin W-stat & -5.32003 & 0.0000 & 6 & 424 \\
ADF - Fisher Chi-square & 52.8747 & 0.0000 & 6 & 424 \\
PP - Fisher Chi-square & 95.9960 & 0.0000 & 6 & 444 \\
\hline $\begin{array}{l}\text { Source: Authors' Computation using EViews 10 } \\
\text { ** Probabilities for Fisher tests are computed using an asymptotic Chi-square distribution. } \\
\text { All other tests assume asymptotic normality. }\end{array}$
\end{tabular}

Table 3. Group Unit Root Test: Summary (Model 2) 
Series: PSER, LNGEXP, LNGRVE, LNDEBT, LEXP, YG

\section{Cross-}

\begin{tabular}{ccccc} 
Method & Statistic & Prob. $^{* *}$ & sections & Obs \\
\hline Null: Unit root (assumes common unit root process) & \\
\hline \multicolumn{2}{l}{} & & \\
\hline Levin, Lin \& Chu $t$ & 2.96023 & 0.9985 & 6 & 432
\end{tabular}

Null: Unit root (assumes individual unit root process)

\begin{tabular}{ccccc}
\hline Im, Pesaran and Shin W-stat & -4.09678 & 0.0000 & 6 & 432 \\
ADF - Fisher Chi-square & 49.1401 & 0.0000 & 6 & 432 \\
PP - Fisher Chi-square & 76.9467 & 0.0000 & 6 & 444 \\
& & & & \\
\hline $\begin{array}{l}\text { Source: Authors' Computation using EViews 10 } \\
\text { ** Probabilities for Fisher tests are computed using an asymptotic Chi-square distribution. } \\
\text { All other tests assume asymptotic normality. }\end{array}$
\end{tabular}

Table 4. Group Unit Root Test: Summary (Model 3) 
Series: LEXP, LNGEXP, LNGRVE, LNDEBT, $\mathrm{CO}_{2}$, LNINDO

\begin{tabular}{ccccc}
\hline & & \multicolumn{3}{c}{ Cross- } \\
Method & Statistic & Prob. $^{* *}$ & Sections & Obs \\
\hline Null: Unit root (assumes common unit root process) \\
\hline Levin, Lin \& Chu $t$ & 3.38145 & 0.9996 & 6 & 428
\end{tabular}

Null: Unit root (assumes individual unit root process)

\begin{tabular}{|c|c|c|c|c|}
\hline Im, Pesaran and Shin W-stat & -4.11675 & 0.0000 & 6 & 428 \\
\hline ADF - Fisher Chi-square & 51.2037 & 0.0000 & 6 & 428 \\
\hline PP - Fisher Chi-square & 84.5750 & 0.0000 & 6 & 444 \\
\hline
\end{tabular}

Table 5. Group Unit Root Test: Summary 
Series: $\mathrm{CO}_{2}$, LNGEXP, LNGRVE, LNAGRI, LNINDO, YG

\begin{tabular}{ccccc}
\hline & & \multicolumn{3}{c}{ Cross- } \\
Method & Statistic & Prob. $^{* *}$ & sections & Obs \\
\hline Null: Unit root (assumes common unit root process) \\
\hline Levin, Lin \& Chu $t$ & 15.3236 & 1.0000 & 6 & 416
\end{tabular}

Null: Unit root (assumes individual unit root process)

\begin{tabular}{ccccc}
\hline Im, Pesaran and Shin W-stat & -5.99337 & 0.0000 & 6 & 416 \\
ADF - Fisher Chi-square & 62.2609 & 0.0000 & 6 & 416 \\
PP - Fisher Chi-square & 111.384 & 0.0000 & 6 & 444 \\
& & & & \\
\hline $\begin{array}{l}\text { Source: Authors' Computation using EViews 10 } \\
* *\end{array}$ \\
All other tests assume asymptotic normality.
\end{tabular}

Table 6. Group Unit Root Test: Summary 
Series: POVTY LNGEXP LNGRVE LNDEBT LNAGRI YG

Unrestricted Cointegration Rank Test (Trace)

\begin{tabular}{ccccc}
\hline $\begin{array}{c}\text { Hypothesized } \\
\text { No. of CE(s) }\end{array}$ & Eigenvalue & Statistic & Critical Value & Prob. $^{* *}$ \\
\hline None * & 0.459325 & 131.1681 & 95.75366 & 0.0000 \\
At most 1 & 0.347330 & 86.27772 & 69.81889 & 0.0014 \\
At most 2 & 0.309375 & 55.12980 & 47.85613 & 0.0089 \\
At most 3 & 0.241418 & 28.10821 & 29.79707 & 0.0773 \\
At most 4 & 0.085148 & 7.938005 & 15.49471 & 0.4721 \\
At most 5 & 0.019553 & 1.441522 & 3.841466 & 0.2299 \\
\hline
\end{tabular}

Source: Authors' Computation using EViews 10

Trace test indicates 3 cointegrating eqn(s) at the 0.05 level

* denotes rejection of the hypothesis at the 0.05 level

**MacKinnon-Haug-Michelis (1999) $p$-values

Table 7. Cointegration Result for Model 1 
Series: YG LNGEXP LNGRVE LNDEBT PSER $\mathrm{CO}_{2}$

Unrestricted Cointegration Rank Test (Trace)

\begin{tabular}{ccccc}
\hline Hypothesized & & Trace & $\mathbf{0 . 0 5}$ & \\
No. of CE(s) & Eigenvalue & Statistic & Critical Value & Prob. $^{* *}$ \\
\hline None * & 0.456991 & 130.5152 & 95.75366 & 0.0000 \\
At most 1 * & 0.380386 & 85.93932 & 69.81889 & 0.0015 \\
At most 2 & 0.315426 & 50.99719 & 47.85613 & 0.0246 \\
At most 3 & 0.211246 & 23.33319 & 29.79707 & 0.2301 \\
At most 4 & 0.072541 & 6.010198 & 15.49471 & 0.6943 \\
At most 5 & 0.007000 & 0.512796 & 3.841466 & 0.4739 \\
\hline $\begin{array}{l}\text { Source: Authors' Computation using EViews 10 } \\
\text { Trace test indicates 3 cointegrating eqn(s) at the } 0.05 \text { level } \\
\text { * denotes rejection of the hypothesis at the 0.05 level } \\
\text { **MacKinnon-Haug-Michelis (1999) } p \text {-values }\end{array}$ & & \\
\hline
\end{tabular}

Table 8. Cointegration Result for Model 2 
Series: PSER LNGEXP LNGRVE LNDEBT LEXP YG

Unrestricted Cointegration Rank Test (Trace)

\begin{tabular}{|c|c|c|c|c|}
\hline Hypothesized & & Trace & 0.05 & \\
\hline No. of CE(s) & Eigenvalue & Statistic & Critical Value & Prob. ${ }^{* *}$ \\
\hline None * & 0.407958 & 136.8177 & 95.75366 & 0.0000 \\
\hline At most $1^{*}$ & 0.359880 & 98.55276 & 69.81889 & 0.0001 \\
\hline At most $2^{*}$ & 0.335031 & 65.98752 & 47.85613 & 0.0004 \\
\hline At most $3 *$ & 0.235750 & 36.20241 & 29.79707 & 0.0080 \\
\hline At most $4^{*}$ & 0.127393 & 16.57559 & 15.49471 & 0.0343 \\
\hline At most $5^{*}$ & 0.086793 & 6.627873 & 3.841466 & 0.0100 \\
\hline
\end{tabular}

Source: Authors' Computation using EViews 10

Trace test indicates 3 cointegrating eqn(s) at the 0.05 level

* denotes rejection of the hypothesis at the 0.05 level

**MacKinnon-Haug-Michelis (1999) $p$-values

Table 9. Cointegration Result for Model 3 
Series: LEXP LNGEXP LNGRVE LNDEBT $\mathrm{CO}_{2}$ LNINDO

Unrestricted Cointegration Rank Test (Trace)

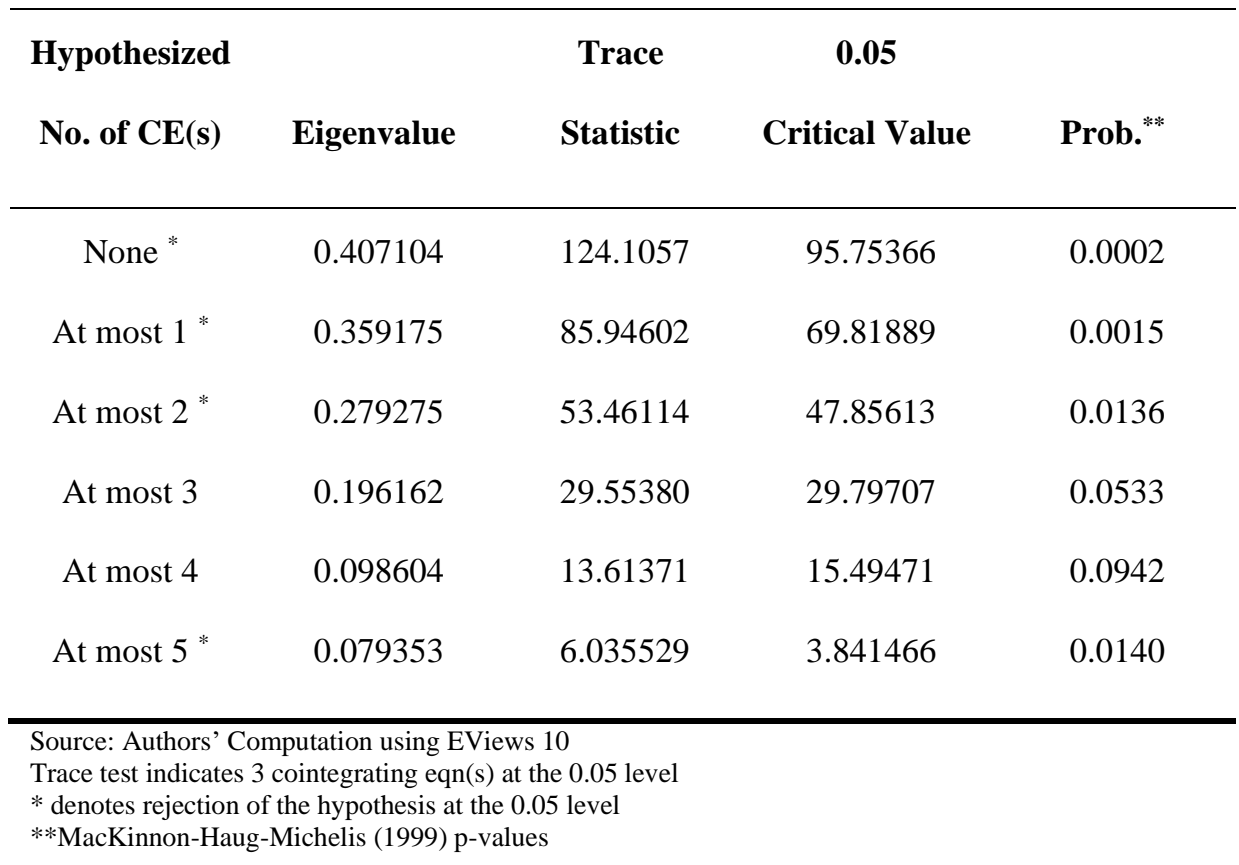

Table 10. Cointegration Result for Model 4 
Series: $\mathrm{CO}_{2}$ LNGEXP LNGRVE LNAGRI LNINDO YG

Unrestricted Cointegration Rank Test (Trace)

\begin{tabular}{|c|c|c|c|c|}
\hline Hypothesized & & Trace & 0.05 & \\
\hline No. of CE(s) & Eigenvalue & Statistic & Critical Value & Prob. ** \\
\hline None * & 0.495038 & 151.9046 & 95.75366 & 0.0000 \\
\hline At most $1^{*}$ & 0.400882 & 102.0257 & 69.81889 & 0.0000 \\
\hline At most $2^{*}$ & 0.319126 & 64.62809 & 47.85613 & 0.0006 \\
\hline At most $3^{*}$ & 0.255055 & 36.56846 & 29.79707 & 0.0071 \\
\hline At most 4 & 0.156526 & 15.07397 & 15.49471 & 0.0578 \\
\hline At most 5 & 0.035617 & 2.647464 & 3.841466 & 0.1037 \\
\hline
\end{tabular}

Table 11. Cointegration Result for Model 5 